\title{
Criteria for the effectiveness of teaching technologies in modern practices of professional training of teachers
}

\author{
Irina Krishtofik $^{1 *}$ \\ ${ }^{1}$ Moscow City University, Institute of System Projects, Moscow, Russia
}

\begin{abstract}
The study presents results of the "Study of the features of the influence of teaching technologies at a university on the formation of professional competencies of students and graduates of a pedagogical university", carried out based on the Moscow City University in 2018-2019. The prerequisite for the study is a situation when education is increasingly beginning to be built around requests from the future, in which people study all their lives and act in a constantly changing world. Therefore, the educational process in a modern pedagogical university is focused on such requirements as complexity, adaptability, practicality, integration into society and the economy, and focus on the needs of students and their future employers. In a university that implements an innovative teaching model, a variety of teaching technologies are used; teachers have the right to freely choose the forms and means of teaching, in connection with which the problem of the effectiveness of the use of teaching technologies is actualized. One of the purposes of the study is to identify criteria for the effectiveness of teaching technologies in the process of forming the professional competencies of future teachers. As a result of the use of survey methods, content analysis, focus groups, and case analysis, 12 criteria were identified: feasibility of using teaching technology, flexibility in application, portability of practice, development of pedagogical thinking, development of soft skills, focus on "self-processes" and "proprocesses", interactivity, practical orientation, as well as digitalization, resource intensity, and efficiency. The results make it possible to analyze and evaluate the effectiveness of teaching technologies in the practice of training future teachers. The novelty of the work and its results are determined by an original approach to identifying criteria for the effectiveness of learning technologies in the educational process of a pedagogical university. Keywords: educational practice, skills of the future, digital technologies, pedagogical competencies.
\end{abstract}

\section{Introduction}

Teaching technology (TT) is the core of educational practice. In connection with the variety of TT existing in universities, the problem of the effectiveness of their application is actualized. It is necessary to answer the question of what the criteria are for the effectiveness of modern practices of professional training of teachers in a university. Based on the

\footnotetext{
*Corresponding author: krishtofik@gmail.com
} 
understanding of effective technology as a technological method, characterized by the economical transformation of resources into products, effective technology of teaching at a university should be understood as a technological way of organizing the learning process and ensuring the most economical transformation of resources into planned educational results. The achieved learning outcomes should meet, on the one hand, the requirements of industry and educational standards and, on the other, social expectations in relation to a modern university, designed to provide students with the formation of " $21^{\text {st }}$ century skills".

\section{Methods}

Methodological basis of the study: competency-based and personality-oriented approaches to the design, implementation, and quality assessment of the educational process; contextual approach to teaching; cognitive taxonomy; theory of constructivism. The criteria identified during the study were tested within the framework of an intra-university competition for the best teaching practices at the Moscow City University in 2019-2020.

\section{Results}

In the course of the study, the following criteria for the effectiveness of TT were identified:

- Feasibility of using TT: compliance of TT to the target block of the learning process (goals, objectives, planned results); correspondence of TT to the content-organizational block - the content of training, forms, methods, and techniques.

- Flexibility in the use of TT: the ability to rebuild its elements when changing tasks or learning conditions; ability to combine TT with traditional TT, to embed an integral TT (at the discipline level) or individual TT components (at the class level) into the educational process.

- Portability of practice: reproducibility of TT due to its algorithmic nature methodological descriptions and flow charts; availability of the teaching materials used open sources of information - electronic libraries, internet coworking spaces, virtual laboratories; availability of the developed tools - Internet resources for creating educational disciplines/modules.

- Development of pedagogical thinking: use of active teaching methods - case, project, research, contextual; problem-based content of training - a problem situation, search and understanding of new information, reflection of methods, evaluation of results; use of techniques for the development of intelligence.

- Development of soft skills: cognitive skills - creative, search, critical thinking, logical thinking, understanding; social and communication skills - group interaction, meaningful communication (listening, questioning, opposing).

- Orientation to "self-processes": processes of self-determination - self-understanding, introspection; self-actualization processes - self-projection, self-realization, selfpresentation; self-regulation processes - self-motivation, self-control, self-esteem.

- Orientation to "proprocesses": students projecting their educational activities - goalsetting, predicting results; programming of their activities - educational, research, professional-practical, social.

- Interactivity: organizational forms that ensure the dialogic nature of learning - pairs, small groups, project teams, collective discussions, educational games; freedom of choice in the educational process - students' choice of content, organizational forms, level of complexity, pace of study; creating situations of success - inspiring assessment, reflection of the student and teacher. 
- Practical orientation: organization of real practical activities of students - distributed practice in schools, internships; filling training with practical educational material - situation analysis, solving practical problems, simulation.

- Digitalization: in the teacher's activities - tools for managing the student's educational activities; in the student's activities - personalization of learning, gamification; digitalization of the work of administrators of the educational process - tools for data collection, accounting, and statistical analysis of learning outcomes.

- Resource intensity of practice: intangible and material resources.

- Effectiveness of the practice: quantitative results - volume indicators, level of achievement of the planned results; qualitative results - external peer reviews, customer satisfaction, recognition of the practice by governing bodies and the public; sustainable effects - new educational precedents and achievements, spread of practice.

\section{Discussion}

These criteria are largely consistent with the position of several researchers. E.A. Sukhanova [1] believes that there are three approaches to the issue of performance. The first examines the effectiveness of educational practice in terms of learning outcomes. This approach provides, on the one hand, a view of educational results as benchmarks and a link between the modules/disciplines of the educational program and, on the other hand, qualitative comparability of results. Our criterion of the effectiveness of practice, which reflects the degree of achievement of educational results, is consistent with this approach. The second approach is "resource". It is based on the comparison of the achieved effect with the costs. Our criterion of resource intensity of practice is fully consistent with it; the fewer resources are spent on achieving the planned results in the required volume and at the required quality level, the more effective the TT. The third approach describes the results in the logic of the process. Within the framework of the training module, it reflects the necessary means at the entrance, the educational technology used in the learning process, and the product at the exit. This approach agrees with the criterion of the feasibility of using TT, which determines its limits of applicability.

A.T. Galiakhmetova and E.A. Andreeva [2] discuss the replacement of individual disparate TT with holistic systems of effective flexible TT (flexible integral technology of design-research, student-centered and computer learning). A.V. Zhiryakova [3] believes that flexible learning is based on the principle of freedom of choice, according to which students are given a choice of place, method, and pace of learning. This choice can take place in any ICT-supported educational practice. Agreeing with the above positions, we propose a criterion of flexibility in the use of TT, which makes it possible to assess the possibility of rearranging its elements for the solution of any learning problem, when the learning context changes.

The significance of the criterion of portability of practice is confirmed in the study of Hui-Ching Yeh and Sheng-Shiang Tseng [4], who consider a model for the development of professional skills of teachers when they develop lessons using computer programs. A.M. Toda et al. [5] believe that the reproducibility of technology is achieved by gamification focused on educational goals.

O. Chernikova, N. Heitzmann, M. Stadler, D. Holzberger, T. Seidel, and F. Fischer [6] draw attention to the possibilities of TT for the development of complex skills and professional thinking. In this regard, such a criterion as the orientation towards the development of the professional thinking of the future teacher will make it possible to assess the extent to which the processes of critical, divergent, and reflexive thinking are stimulated in teaching practice. 
The focus on the development of soft skills involves the organization of the educational process, in the center of which is the creative activity of students, work in teams, and critical thinking. We agree with E.S. Akopova, O.I. Glazunova, Yu.V. Gromyko [7, 8], Ch.R. Huber and N.R. Kuncel [9] who believe that the development of soft skills is communication aimed at achieving mutual understanding and creating ways of joint thought activity. We believe that the development of the entire complex of soft skills is due to the need to prepare a graduate for work in conditions of instability, uncertainty, complexity, and ambiguity and their pedagogical competencies should be complemented by "skills of the future".

I. Jivet et al. [10] note that in the framework of blended learning, student goals and selfregulatory learning (SRL) skills influence the formation of the meaning of the educational material. C.-H.Chen and C.-Y. Su [11] and E. Ergün and Ü. Avc1 [12] note the importance of developing the student's ability to act independently. In educational practice, along with the processes of self-regulation and self-realization, processes of self-determination of students are also necessary. All three groups of processes can be summarized as "selfprocesses". According to what has been said, one more criterion is singled out - an orientation towards self-processes.

The Report "Twelve Solutions for New Education" [13] notes that in OECD countries in the educational process of schools and universities, project activities have begun to occupy up to $30 \%$. Project teams carry out activities aimed at the cognitive analysis of the procedures of project design and goal setting, the development of design mindset [14], as well as the perception of information in conditions of uncertainty, development of prototypes of design solutions, creation of models, and deep data analysis [15]. In pedagogical practice, a significant amount of time is allocated for such processes (which we named generically as proprocesses), such as: students projecting their educational activities, including goal-setting, setting educational tasks; programming of educational activities; predicting their educational results. Our criterion is proprocess orientation.

A. Maarit and H. Raija [16] argue that learning activities are increasingly carried out in interactive groups, which allows one to analyze the joint learning activities of students from the point of view of their dialogicity, with which our criterion of interactivity is consistent.

Many researchers, including N.A. Asipova [17] and E.A. Drugova and O. N. Kalachikova [18], believe that the effectiveness of teaching in a pedagogical university depends on the use of methods for organizing real practical activities of students. An interested employer should participate in the learning process as a provider of complex practical problems, the solution of which in the learning process provides the student with the opportunity to cope with similar tasks in the future. Hence one more criterion of efficiency - the practical orientation of TT.

N.V. Dvoryanchikov [19], A.A. Margolis [20], and Ya.M. Roshchina [21] draw attention to the trend towards the creation of smart universities that can provide an opportunity for students to build their own individual competency profile that is in demand in the labor market in the digital economy. Digitalization of higher education is taking place, manifested in the use of various formats of digital technologies. Therefore, the digitalization criterion is necessary to assess the effectiveness of digital tools used in the practice of training future teachers.

\section{Conclusion}

The criteria for the effectiveness of TT, identified as a result of the study, are intended to be used as a complex criterion system for analyzing and evaluating the practice of professional training of a modern teacher in a pedagogical university.

Further research of the criterion system for evaluating TT in educational practice involves an analysis of its capabilities in terms of covering the main changes in the process of vocational training in a pedagogical university. 


\section{References}

1. A.A. Abbasova et al, Razrabotka metodiki analiza effektivnosti magisterskikh programm[Development of a Methodology for Analyzing the Effectiveness of Master's Programs] (National Research Tomsk State University, Tomsk, 2019). Accessed on: December 20, 2020. [Online]. Available: http://www.tsu.ru/upload/medialibrary/ce3/kollektivnaya-monografiya-fondpotanina.pdf

2. A.T. Galiakhmetova, E.A. Andreeva, Kazan pedagogical journal, 2 (2017)

3. A.V. Zhiryakova, Modern Problems of Science and Education, 5 (2016)

4. H.-C. Yeh, S.-S. Tseng, Educational Technology Journal, 22(3) (2019)

5. A.M. Toda, P.T. Palomino, W. Oliveira, L. Rodrigues, A.C.T. Klock, I. Gasparini, A.I.Cristea, S. Isotani, Educational Technology \& Society, 22(3), 47-60 (2019)

6. O. Chernikova, N. Heitzmann, M. Stadler, D. Holzberger, T. Seidel, F. Fischer, Review of Educational Research, 90(4), 499-541 (2020). https://doi.org/10.3102\%2F0034654320933544

7. E.S. Akopova, O.I. Glazunova, Yu.V. Gromyko, Psychological Science and Education, 25(2), 5-18 (2020). https://doi.org/10.17759/pse.2020250201

8. O.I. Glazunova, Yu.V.Gromyko, Psychological Science and Education, 24(5), 58-70 (2019). https://doi.org/10.17759/pse.2019240506

9. Ch.R. Huber, N.R. Kuncel, Review of Educational Research, 86(2) (2016) https://doi.org/10.3102/0034654315605917

10. I. Jivet, M. Scheffel, M. Schmitz, S. Robbers, M. Specht, H. Drachsle, The Internet and Higher Education, 47 (2020). https://doi.org/10.1016/j.iheduc.2020.100758

11. C.-H. Chen, C.-Y. Su, Educational Technology \& Society, 22(4), 33-46 (2019)

12. E. Ergün, Ü. Avc1, Educational Technology \& Society, 21(3), 60-73 (2018)

13. Center for Strategic Research, Dvenadtsat reshenii dlia novogo obrazovaniia [Twelve Solutions for New Education] (Center for Strategic Research, Moscow, 2018). Accessed on: December 20, 2020. [Online]. Available: https://www.hse.ru/data/2018/04/06/1164671180/Doklad_obrazovanie_Web.pdf

14. H. Weber, S. Gancho, A. Mateus, A.C. Rodrigues, Varying Mindsets in Design Thinking. Why they change during the process and how to nudge them, in Proceedings of the 6th Design Doctoral Conference, Universidade Europeia, 22-24 ${ }^{\text {th }}$ May 2019, Lisbon, Portugal, 45-52 (2019)

15. P. Cash, M.E. Kreye, Design Studies, 54, 50-79 (2018). https://doi.org/10.1016/j.destud.2017.10.004

16. A. Maarit, H. Raija, The Internet and Higher Education, 48 (2021). https://doi.org/10.1016/j.iheduc.2020.100771

17. N.A. Asipova, International Journal of Applied and Fundamental Research, 6, 175-179 (2018). Accessed on: December 20, 2020. [Online]. Available: https://appliedresearch.ru/pdf/2018/2018_6.pdf

18. E.A. Drugova, O.N. Kalachikova, University Management: Practice and Analysis, 23(1-2), 81-92 (2019). https://doi.org/10.15826/umpa.2019.01-2.006

19. N.V. Dvoryanchikov, T.V. Kalashnikova, L.S. Pechnikova, N.V. Frolova, Psychological Science and Education, 21(2), 76-83 (2016). https://doi.org/10.17759/pse.2016210209 
20. A.A. Margolis, Psychological Science and Education, 23(3), 5-19 (2018). https://doi.org/10.17759/pse.2018230301

21. Ya.M. Roshchina, S.Yu. Roshchin, V.N. Rudakov, Education Issues, 1, 174-199 (2018) 